\title{
Local Wisdom to Overcome Covid-19 Pandemic of Urug and Cipatat Kolot Societies in Bogor, West Java, Indonesia
}

\author{
Bahagia Bahagia ${ }^{1 *}$, Bambang Hudayana ${ }^{2}$, Rimun Wibowo ${ }^{3}$, Zuzy Anna ${ }^{4}$ \\ ${ }^{1}$ Universitas Ibn Khaldun, Jl. Sholeh Iskandar, Kota Bogor, Jawa Barat 16162, Indonesia \\ ${ }^{2}$ Universitas Gadjah Mada, Bulaksumur, Caturtunggal, Kabupaten Sleman, Yogyakarta 55281, \\ Indonesia \\ ${ }^{3}$ STIMMA IMMI Jakarta, Jl. Tj. Barat Raya No.11, Kota Jakarta Selatan, Jakarta 12530, Indonesia \\ ${ }^{4}$ Universitas Padjajaran, Jl. Dipati Ukur No 46, Bandung, Jawa Barat 45363, Indonesia \\ *) Corresponding Author (bahagiagia59@yahoo.co.id)
}

Received: 20 October 2020 / Accepted: 01 December 2020 / Published: December 2020

\begin{abstract}
Local wisdom can be interpreted as principles of life, behaviour, rules, and punishments, as well as a view of life that regulate life, so that it can regulate and managing natural resources in the natural, social, and economic environments. Even local knowledge have adapted to environment obstacle. This research aims to investigate traditionally local knowledge for confronting Covid-19 pandemic. The method used is qualitative with an ethnography approach and literature review. Data are collected through in-depth interviews with leaders of Urug and Cipatat Kolot societies. In order to investigate Baduy and Ciptagelar communities used a literature review. Data are supported by documentation and observation sources. The sample is selected using a purposive sampling technique. The result is analysed through triangulation, which is by mixing some gathered data methods. The result is that Urug society allocates rice each year from their paddy yields to the vulnerable groups such as orphans, elderlies, widows, and persons need most. Secondly, collective action is used to jump the capacity of people like women through nujuh bulanan. Thirdly, societies exert taboo to combat disaster and Covid-19, including by prohibiting community from trading paddies and rice. Another finding is that indigenous knowledge uses some life strategies and utilizes natural capital optimally for overcoming life perturbances. The last finding is that local knowledge has preserved agriculture jobs as a venue to survive.
\end{abstract}

Keywords: Adaptation, Covid-19, local knowledge, taboo, livelihood.

\section{Introduction}

Covid-19, as a global pandemic, has impacted all countries in the world and whole aspect of life. Paoudel et al. (2020) said that Covid-19 had impacted livestock production, poultry, fishery, and dairy production. Covid-19 also halts planting crops. Omer \& Hassen (2020) reveal that in agriculture, usually in production, Covid-19hasanadverse impact on crop and livestock production inputs, labor shortages, psychological aspects of producers, agricultural expansion support systems, support/service providers, local government, desert locust control, and religious movements. Udmale et al. (2020) reveal that Covid-19 results to disturb food supply. Farmers, retailers, and stakeholders wonder what occurs next time (Jámbor, Czine \& Balogh, 2020). The price of food continues to soar as the cause of the farmer level's lack of production. Covid-19 has hindered food production, processing, and marketing (Devereux, Béné \& Hoddinott, 2020).

In the level of production, farmers confront to stop their production because they are restricted by a lack of seed, fertilizer, and pesticide. After all, the staller is closed during a pandemic (Poudel et al., 2020). Even this impacts transportation, which can hamper the delivery of seed, fertilizer, and pesticide from the import mechanism (Hossain, 2020). Meanwhile, the pandemic 
also has an impact on fish, plant, and milk farmers. Dairy farmers must dump their milk because industry which receives milk for creating product must be closed. Developing countries are the most affected due to their high dependency on securing their food supplies (Mouloudj, Bouarar \& Fechit, 2020). In a short time, closing restaurants and schools results to complete loss of an entire distribution channel, which has had the most dramatic impact (Richards \& Rickard, 2020). The adverse impact of lockdown during the Covid-19 pandemic results to give rise to a shortage of labour forces and logistic disruptions, eventually in supplyside shocks to the food supply chain (Singh et al., 2020).

Other issues affected are a shortage of agricultural labours. Meanwhile, lack of agriculture profit can postpone some activities, including sowing, fertilizer, irrigation, shrub cleaning, and harvesting of yields (Seleiman et al., 2020). Another case is that the Covid-19 outbreak leads to creating people's shocking buying and stockpiling (Hassen Bilali \& Allahyari, 2020). Even the hoarding of staples occurs, leading to market disruption. Other impacts are ranging from changes in small and large scale agricultural businesses' behavior due to changes in behaviour by farmers themselves and behaviour that is altered by consumers (Kolodinsky \& Sitaker, 2020). It can increase human malnutrition because the shortage of food leads to a lack of nutrients. Bhavani \& Gopinath (2020) reveal that hunger and malnutrition are expected to increase, and the poor and vulnerable will suffer the most.

It can be compounded by a lack of exercises when the lockdown has been determined, leading to excessive food consumption, which has stockpiled. The high rate of diets high in saturated fats, sugars, and refined carbohydrates (collectively called Western Diet, WD) worldwide contributes to the prevalence of obesity and type 2 diabetes. In another case in the enterprise, a decrease in total sales revenue of $53.5 \%$ was found. The issues about food obstacles amid the Covid-19 pandemic can be overcome with a local knowledge approach.
Local knowledge such as Urug and Cipatat Kolot societies have enhabited in the countryside. When the restriction policy is conducted, food distribution can be hindered because the transportation halts temporarily. It can be compounded by long distances and extremely bad road facilities that restrict societies from obtaining fundamental necessities. However, indigenous knowledge has acted for a longstanding time for confronting eco-catastrophe and outbreak. When Covid-19 strikes people's life, these people can withstand this hurdle. Local knowledge has numerous actions for combating life perturbances because people have a long-standing experience overcoming environmental stressors.

Local knowledge has numerous actions for combating life perturbances because they have a long-standing experience to overcome some environmental stressors. According to Syarif (2017), local wisdom is in the form of knowledge, myths, and ancestral messages which contain prohibitions, invitations, and sanctions in environmental management. Local wisdom includes the values of life that apply to the community in the form of wise, wisdomfilled local ideas embedded and followed by residents to protect a sustainable environment (Takiddin, 2014). Local wisdom has also evolved together with the community and experienced collectively [experienced what?] (Wahongan \& Soputan 2016). Sources of local knowledge can come from customs, religion, ancestral advice, and local culture used to adapt to the environment (Rachman \& Alam, 2017).

Mawaddahni(2017) states that local wisdom also consists of a view of life and knowledge, consisting of various livelihood strategies to solve life problems. Local wisdom is important to be preserved to maintain environmental balance and sustainability. Local knowledge has adapted and interacted with the environment to find adaptation strategies to the environment at the local level (Manrique et al., 2018). Local wisdom is also related to spiritual values, metaphysics, natural sciences, and abilities to adapt to social changes (Mazlan \& Omar, 2012). This knowledge is transferred by word 
of mouth to the next generation (Rosmaidar, 2020). The accumulation of knowledge and production is instilled in the community through social interactions or relationships. Knowledge involves transforming knowledge into applicable ways to increase resilience. Local knowledge is a source of resilience because local knowledge is integrated with the socioecological system, enabling the community to overcome complexity and uncertainty problems. This knowledge is very accurate to be used as a guide for life (Gorda, Anggria \& Wardani, 2020).

Harahap (2020) said that local knowledge had been integrated into belief and culture manifested in the form of tradition. This knowledge is sage locally and obeyed by the local community (Nasution \& Taupiqqurrahman, 2020). Local wisdom can be interpreted as an idea, principles of life, behaviour, rules or norms, and punishments and a view of life that govern life locally and are globally valuable, so that it can regulate the various ins and outs of life, including managing resources, nature, both living and dead environments, regulating social life, and regulating economic matters. Tryanto (2017) reveals that the holistic approach contained in local wisdom makes humans have an inner bond with nature and the environment and other living things so that it grows into a sense of concern for the preservation of nature and its contents.

This is reinforced again that local wisdom is classified as intelligence obtained based on experience. The manifestation of local wisdom starts from the prohibition to not damage the environment, such as forests and water (Niman, 2019). This prohibition can come from culture and religion. In religion, the prohibition of eating gripping animals such as eagles, owls, and kestrel plays a role in maintaining the balance of rat population, and the prohibition on killing frogs serves to control the insect population. This is the case with the ihya-alamawat rule or reviving dead soil because the soil must be turned on as well as be conserved (Ikhtiono et al., 2020). Seprianto, Suminar \& Nopianti (2017) were with the belief that the hill of prohibitions is seen as a sacred place that cannot be touched and entered by the community, so that forest resources are used collectively as joint property and not monopolized by individuals and groups so that environmental damage is reduced. Another form of local wisdom is rantau prohibition. This area is designated as a prohibited area by customary stakeholders by determining the area on the river not allowing fish to be harvested unless it is time for fish harvesting (Oktaviani, Prianto \& Puspasari, 2015). This local knowledge is also known as lubuk prohibition. The community determines the river area where fish is not allowed in the area (Ilhami, Riandi \& Sriyati, 2018).

The application of local wisdom can also be seen, such as from the implementation of Sasi in Maluku. In this area, it is prohibited, so that it is not allowed to take certain resources aimed at environmental conservation and equitable distribution of resources for the community (Widarmanto, 2018). There are regulations that regulate where land and sea areas are not allowed to be harvested for a certain period (Lerebulan, Girsang, Siwalette, 2018). Conservation of the sea and islands is carried out by determining the weather and fishing season and by using environmentally friendly fishing gears (Ali \& Sinilele, 2019). The forms of local wisdom are Sasi and lubuk prohibitions on destroying valuable forests for Covid-19 control. Environmental disasters, in general, will have an impact on food availability. Food preservation as a source of foodstuffs for plants, fish in the river, and fish in the sea plays an important role in maintaining food sources, both staple foods, and animal protein sources. Three things must be considered in realizing food security, including food availability, food access, and food utilization (Gantini, 2015). Meanwhile, food system resilience can be defined as humans' ability as actors in the food system, learning from experience and developing a variety of new capacity structures to improve results (Skog et al., 2018). Also, food system resilience includes human ability to produce food and access to nutrition and culture that is acceptable to deal with change and disruption (Meagan et al., 2016). 
Many disturbances that occur ranging from climate change, an increase in earth temperature, and extreme weather. Food system resilience can also be defined as the ability to survive, adapt, and transform when uncertain conditions. The resilience of the food system also includes robustness in its ability to withstand stress and surprises. Meanwhile, adaptability is the capacity to change the composition of inputs, production, marketing, and risk management in response to shocks and stresses without changing the agricultural system's structures and feedback mechanisms. This research will focus on the local wisdom of the people in the province of West Java, including the Ciptagelar indigenous people, the Baduy indigenous people, Urug, Cipatat Kolot societies, and Naga society. There are several objectives to be achieved, like, firstly, how Urug society empowers susceptible groups including orphans, elderlies, widows, and persons who need most for helping to jump the capacity to face catastrophe like Covid-19. Secondly, this is to find out about collective action to increase people's power when they confront a disaster like Covid-19. Thirdly, this is to find out how the role of pamali or prohibition rules as a way to maintain food security so that it can be a way to overcome various environmental disasters, including the Covid-19 pandemic. Another goal is to find ways or livelihood strategies that can be used to solve life's problems, including ecological disasters and the Covid-19 outbreak. Lastly, this is to find out why they are farmers rather than choosing other places to survive.

\section{Methods}

The research is conducted in Urug and Cipatat Kolot Villages, Sukajaya Subdistrict, Bogor Regency, West Java, Indonesia. Various villages border urug village, in the north, urug village borders Harkat Jaya village, in the south by Kiara Sari village and Curug Bitung village, in the east by Nanggung Village and in the west by Cisarua and Pasir Madang village. While Cipatat Kolot societies close to Urug societies in Urug village. The map location of this research can be viewed in Figure 1 below.

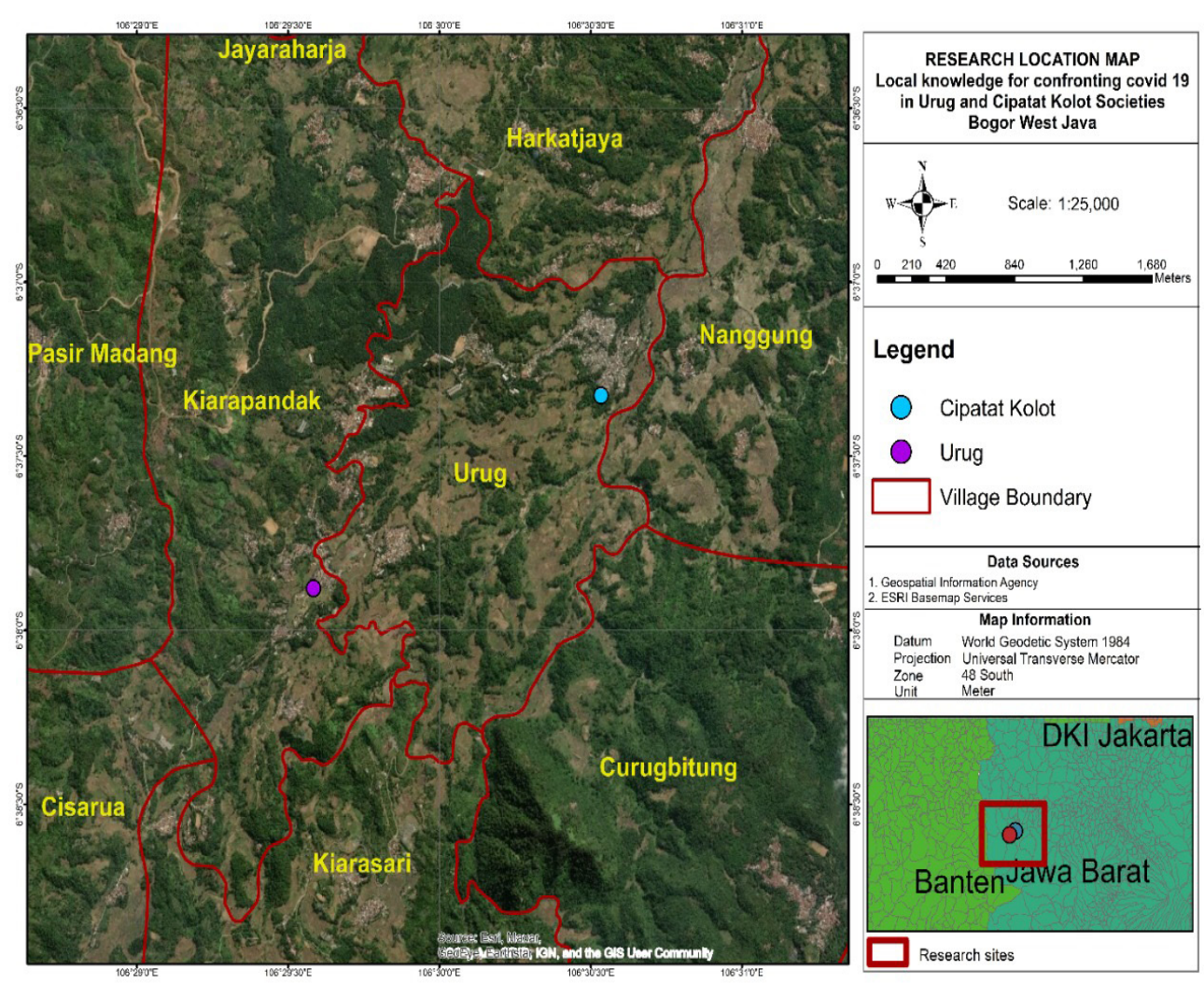

Figure 1. Location of study area. 
The research uses a qualitative method of an ethnographic approach. Ethnography is studied concerning societies and cultures based on the prediction, which is valuable for perpetrators (Thohir, 2019). The focus of ethnography is the relationship between social groups or cultural actors with their interactions (Beta, Herdiana, Salvia, 2020). The ethnographic approach belongs to research with a naturalistic point of view (Adim, 2020). To obtain data with ethnographic research is by following the community's life activities that will be studied. Plunging directly into social life that will be observed will gain more clearly obtained information. Qualitative research aims to describe the problems that exist in the social environment (Mohajan, 2018). Meanwhile, qualitative research collects data by employing case studies, personal experiences, introspection, curriculum vitae, interviews, observations, and social. Sukadari, Suyata, \& Kuntoro (2015) say that qualitative research describes life experiences to be studied with meaningful explanations. This research prioritizes meaningful descriptions rather than generalizations (Nugraha, 2015). Meanwhile, ethnographic research uses indepth, qualitative, and holistic-integrative analysis (Koeswinarno, 2015).

Besides using the ethnographic research method, this study also uses theliterature review research method. This approach is carried out by searching for sources of research information related to the topic. The results are analysed, compared, and linked with the research objectives to be achieved. The literature review is conducted for some societies, including Naga society, Baduy, and Ciptagelar communities. Meanwhile, the determination of the sample for the qualitative ethnographic method used purposive sampling. This technique is done by determining which respondents are deemed worthy and can explain the research objectives following. There were four resource persons involved, namely the Customary Heads of the Urug and Cipatat Kolot people. The samples included Abah Ukat and Abah Maman from Urug indigenous community, while Abah Sachin and Abah Nurhasim from Cipatat Kolot indigenous community.

Meanwhile, the Baduy community was not interviewed but by looking for research articles that had been researched and linked to the Covid-19 disaster. For collecting data in the field, the researcher uses three sorts of methods, including observation, in-depth interviews, and documentation. Observation in this research is conducted through observing the locations of Urug and Cipatat Kolot societies. Furthermore, the researcher views and takes notes to the location of the leuit, which saves paddies as fundamental stock for societies. Even the researcher sees societies' behaviour for cultivating local paddies as proof that agricultural behaviour is released in Urug and Cipatat Kolot societies. The researcher also involves togetherness in Urug ceremony like nujuh bulanan ritual where the household mother creates traditional food to be distributed to pregnant women. It is collective behaviour where it concerts decision. All the data from observation are recorded. Secondly, the researcher exerts in-depth interviews that are equipped by mobile phone, which is implied to record the interviews.

There are some aspects that the researcher expects as further results when an interview is held, including data about empowering vulnerable societies such as orphans, elderlies, widows, and people need most about assistance. Another aspect is collective action based on societies like nujuh bulanan which can be used as a way to save a person from being vulnerable because it typically releases when the women experience pregnancy for the first time. The other expected results are about the role of pamali or certain restrictions set locally by indigenous people, including the prohibition not to sell foodstuffs such as rice and paddy. This prohibition is in oneway worthy to overcome Covid-19 because when Covid-19 attacks humans, the problem 
of food scarcity, food prices, food distribution, and access to food is disrupted. Then, data relating to adaptation will be sought because the adaptation of indigenous people appears to go through the challenges of the era until now.

This adaptation behaviour belongs to indigenous people's example to overcome Covid-19 because humans who are affected by Covid-19 must adapt to survive the pandemic or outbreak. Besides, indigenous people can optimize physical resources such as land and combine and carry out two or more activities to earn a living. This condition enables indigenous people to survive under challenging conditions compared to relying on one type of work alone. During Covid-19, this method could be used because many people lost their jobs and could not get other jobs because they relied on one type of job. Finally, why does agricultural work become a job for indigenous people who do not want to work in other sectors rather than being farmers? There is a connection with the food supply. When modern people do work outside agriculture, they lose their jobs when Covid-19 occurs, but indigenous people do not lose their jobs as farmers.

Eventually, the researcher also uses documentation to strengthen the data. All the data which come from three sorts of sources are analyzed by triangulation. Honorene (2016) states that triangulation involves using multiple data sources in an investigation to produce understanding. Time triangulation is to collect data based on time (morning, daylight, and evening). In this research, all of the data from several sources such as observation, in-depth interviews, and documentation are combined and analyzed for deriving valid data. The results from mixing numerous data can be mentioned as trusted data in this research and answer the research's objective.

\section{Result and Discussion}

\subsection{Covid-19 Spreading in Bogor}

Covid-19 is a heavy outbreak in the world, both national and local levels. Bogor is one regency in Indonesia which is impacted by Covid-19 strike. The map depicts the number of subdistricts which is attacked by the outbreak of Covid-19. It is clear to say that there are two categorizations in this map based on colours as distinguishing, namely red as a subdistrict which is positively active and yellow as active PDP (Patient Under Monitoring). The number of active subdistricts in Bogor is about 19, and the active PDP is about 37 subdistricts. The map for spreading of Covid-19 spot can be viewed in Figure 2.

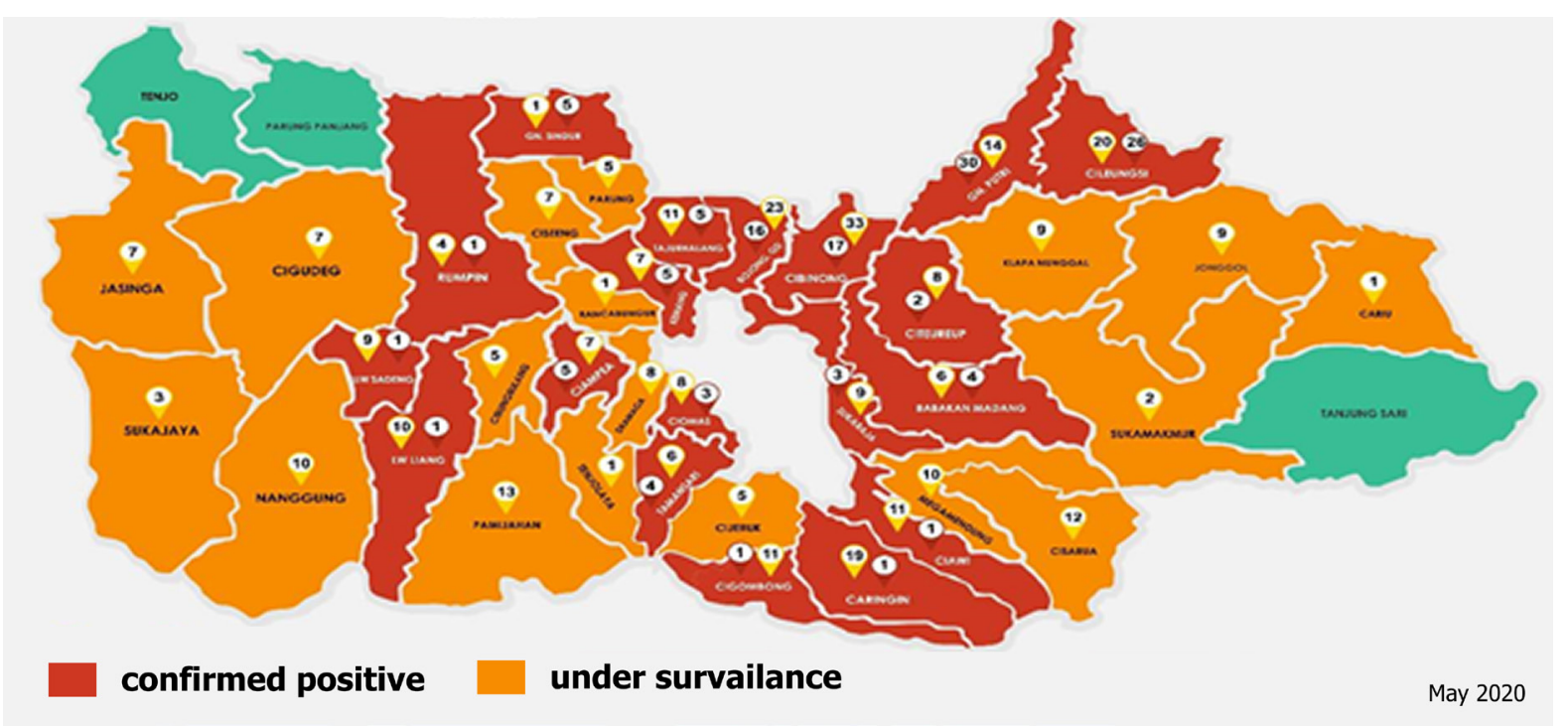

Figure 2. Map for spreading of Covid-19 (Sources: PPI ID Kabupaten Bogor, 2020). 
Based on the map, it clears to explain that Bogor is one regency as a spreading place for Covid-19. The outbreak of Covid-19 like this has an adverse impact on human life, including people confronting to the scarcity of food because the production of food has been disturbed by Covid-19. Covid-19 influences the food supply and demand channels, which indicates a decrease in food stock and a rise in food price. Covid-19 also affects to jump of demand for food because people stay at home, but they disburse money more for it (Workie et al., 2020). Ayanlade \& Radeny (2020) said that Covid-19 disturbs planting seasons. Galanakis (2020) reveals that farmers are restricted in accessing markets, buying inputs, and selling products. However, local knowledge has combated perturbances of life for a long period of time. In a remote area, local knowledge can mitigate disaster and Covid-19 as a disaster (Nugraha, 2020). Some actions can be gathered from local knowledge for handling disasters like flooding, drought, climate changes as well as Covid-19 outbreak. Customary Urug society has confronted disasters through collective action based on their forefather's heritage. In Urug society, it is still found some persons who can be involved as vulnerable people such as an orphan, elderly, widow, destitution person, and former mosque chief who have become elder.

Yanti, Priyanto \& Zulfikar (2020) said that an older person has a higher susceptibility to being infected with the coronavirus compared to a younger age. It can be encouraged that elder people can be categorized as vulnerably impacted to Covid-19 (Siagian, 2020). Farkas \& Romaniuk (2020) reveal that a vulnerable person encompasses elder chronic health conditions, including heart disease, asthma, or diabetes. They confront hurdles when ecocatastrophe and Covid-19 occur, combating their life typically for deriving fundamental needs, including rice. However, the tradition and culture of Urug people have teaching to empower the vulnerable persons. The societies render fundamental food like distributing the rice after harvesting of paddies each year.
The people accept rice every year regularly, without any person denies this tradition. When Covid-19 threats the environment, they can survive because each person has chores to distribute some from their wealth to render to those categorized persons.

\subsection{Indigenous Food Security Adaptation}

Building a resilient food system, especially in terms of food security, to deal with various disasters such as the Covid-19 pandemic virus must learn from indigenous people. Covid-19 has impacted food insecurity where the societies experience a lack of food and have the burden of getting food because some stallers and markets must be halted from operating. Then, when societies have provided their basic food for facing disasters, it means that societies have adopted disaster risk management. The major impact of disasters Covid-19 is a scarcity of fundamental necessities. Meanwhile, disaster risk management, including adaptation, can reduce the risk of Covid-19 to societies because security food can empower people. Meanwhile, adaptation can be mentioned as a response before disaster, loss, or impacts inand after the disaster in the long term to reduce vulnerability and enhance resilience (Zhou \& Wang 2016). There is a common consensus among societies to build and preserve leuit as food storing to ensure security food during unpredictable situation.

It is similar to conduct seren taun (ceremony to begin for cultivating of paddies). Each member of societies agrees and receives local rules, and no person refutes this common determination. Another consensus can be viewed is when Urug society decides the period of paddies cultivation. All of society members follow local traditional rules. It can be utilized to combat Covid-19. When the government decided that all of the people exert mask and do not go outside of house amid Covid-19 outbreak, society must bolster the government who has created those rules. They do not breach the policy. Conversely, in real fact, many people go outside of the house without protecting themselves by way of using masks. 
People are still involved in collective work. As modern societies like traditional societies who act as adherers of the Head, Covid-19 is easier to overcome. Another way for facing Covid-19 is based on local people is to cultivate more than one kind of plants in one location. For instance, drying land which is planted by paddies must be combined with some of the other plants like chilly. As paddies have been garnished, the farmers still can collect chilly yields in another time.

Urug society also applies the way like in Kampung Naga, where the society uses the local patterns for cultivating paddies. There are two mechanisms for planting paddies namely Urug people farm their local paddy varieties, and another time mechanism is that they follow cultivating pattern from the government. Besides, local societies like the Urug community can combat life disturbances because they have provided paddies as staple stock for facing perturbance in the next cultivation period. For example, Urug people save paddies to fulfill fundamental needs until meeting other schedule periods for cultivating paddies. When Covid-19 hits our life, the way of Urug society must be implied in the agricultural sector, typically for the modern farmers. The farmers must change their behaviour to keep paddies until another time for planting comes. It results to avoid farmers from the scarcity of food amid Covid-19 outbreak. Then, leuit as traditional building for storing paddies is severely near to the houses of the community. It produces some advantages in developing societies that do not require purchasing food in long distances because they can gather food close to their house. It is collaboration for confronting Covid-19 pandemic when societies have a heavy burden to fulfil fundamental necessities because they fear to go outside of the house. It can be exacerbated by social distancing, which can have a heavy burden for some people such as the elderly, vulnerable person who cannot work, and limited access to food.

3.3. Collective Adaptation against Covid-19

There are several rituals and traditions in Urug society that are released through collectiveness instead of individual behaviour, such as Nujuh Bulanan ritual and ceremony. In this ceremony, all of the societies must allocate space-time to attend and release this ceremony. It makes them, where women, especially mothers, hand over food traditions like dried and wet food to women who experience pregnancy. It shows that society utilizes power collectively, and concerting actions can jump the rate of individuals' capacity for facing catastrophe. When there is a disaster like Covid-19, it can be adopted by a modern person to react to collective behaviour for assisting other people. Another action is to store food as stock. Indigenous knowledge, including Urug and Cipatat societies, has combated the environment's stressors by saving paddies rather than rice. It is similar to some customary societies, including Baduy and Ciptagelar. Traditional societies salvage paddies in traditional storage, namely leuit. Even they ban members of societies from trading rice and paddies. It is better to save it in anticipation of a disaster that can threaten human life unpredictably. They have provided fundamental food before the catastrophe occurs.

Meanwhile, adaptation can be categorized as collective action to strengthen the power of susceptible people. The behaviour to distribute rice to people as a real fact of that action has empowered the delicacy of group society. It is the form that Urug society has heavy solidarity inside of the group. It can be categorized that the people of Urug society are conscious of their individual responsibility toward collective awareness. They perceive that vulnerable persons have entitlement in their wealth, and they must allocate to a person who requires it. It can be exemplary from Urug society that each person must pay attention to people who suffer from food shortage. As Covid-19 has attacked the human environment, the willingness and the tradition of Urug society can be applicated in downy and village, as well as city environment to assist people who need helping for fulfilling fundamental necessities. 
Immediately, it preserves the agricultural sector because tradition is working fully in farming. Meanwhile, societies that continue agriculture can be mentioned as the persons who have assisted other people amid Covid-19 because all people are fully dependent on agriculture because a big number of human needs come from the agricultural sector. Another action of Urug society is that the people work collectively in a social environment.

The adaptation can also be categorised as a social adaptation because societies together to reduce disasters (Nurjihan Habiba, Nurdin \& Muhamad, 2017). This adaptation is also classified as adaptation where society does not change these changes but adapts to changes (Sutigno \& Pigawati, 2015). All people have leuit for storing paddies. The leuit has been constructed a long period before Covid-19 pandemic occurs. Food security has heavily been connected with this way because, in a short period, societies can fulfill their fundamental need for long term although Covid-19 hits human environment, and human still has the power to deal with Covid-19 through adequacy of food. Indigenous societies are customary science that applicate togetherness or common consensus. Each member of society hears the chief of society. Each remark which comes from the leader, societies follow what the chief intends to do. For example, in Urug society, people determine to conduct traditional ceremonies or rituals, namely earth alms and seren taun. Sedekah Bumi (Ceremony after harvesting). It is released when traditional societies have gathered paddy yields from the fields.

Lastly, facing Covid-19 can adopt mutual working or mutual assistance based on collective action rather than individual. Generally, activity in Urug society and other traditional societies conducts cooperative action based on mutual helping. For instance, as there is a disaster devastates the houses of the members. Another member of societies helps without hoping obtaint wage from that behavior. There is a hope when assisting other persons like thinking that it produces advantages at another time. People who behave it will gain benefit (Mujahidin et al., 2020). Togetherness tradition is valuable when it implements for overcoming Covid-19. The person who is impacted by Covid-19 requires mutual assistance from social environment where the person settles. People in the vicinity must be responsible to help, especially for fulfilling basic need because a person cannot go outside from house to avoid spreading Covid-19 widely. Besides, giving social spirit collectively impacts to increase the life spirit of the victims rather than the social environment which isolates the victims. Otherwise, each person requires another person to attend for help when an individual is impacted by Covid-19. Even, acting collectively for combating Covid-19 such as advising persons who do not exert mask can decline the number of Covid-19 victims.

\subsection{Multiple Sources of Livelihood}

Natural capital comes from household control over land, water that supports household life in survival (Rohmah, 2019). The higher the level of sustainability of natural capital, the higher the livelihood strategy of farmers, and it is not limited to survival (Putra \& Suprianto, 2020). Meanwhile, the use of the two lands includes the use of natural capital and at the same time combines the two strategies to deal with catastrophic food failure. When a failure occurs in one location, it can still be replaced with crops from another location. This example can be used to deal with various disasters including floods, landslides, climate change, and overcoming Covid-19. Farmers who can produce rice are not only focused on growing lowland rice, but cultivating dry land as a location for planting rice is more important. If rice cultivation is successful in both locations, the yields will be even more. One of the problems with food scarcity during the Covid-19 period was that the land needed to be optimized, including dry land and home gardens which were classified as dry land. Dryland for the yard functions socially, ecologically, and also economically. When the 
land is planted, it can control flooding and meet food needs, so that it does not cause social problems such as poverty.

Farmers today are still focused on cultivating rice fields, so that when the Covid-19 disaster struck, the community's food source only came from the rice fields. Meanwhile, dry land still needs to be optimized. Another strategy that must be carried out during the Covid-19 pandemic is to diversify various sources of income. When someone depends on just one source, the community is increasingly vulnerable to calamities and the Covid-19 outbreak. For example, if someone only works for large companies with very high salaries but has to be dismissed or reduced from wages, the family under his control will be more vulnerable. Vulnerability usually leads to stress. Unemployment is growing, and hunger is increasing for just one job. Indigenous people have been able to create various sources of income to survive disasters. Livelihood strategies are divided into three, namely working purely in agriculture, parttime working in agriculture and other fields, and non-agriculture (Yang et al. 2018). This strategy includes a strategy of diversification of livelihoods. Diversification combines two sources of livelihood, such as livestock and trading (Latifunnisa \& Setyowati, 2020).

Besides, multiple livelihoods are released through work outside of agricultural sector, including working as a builder and opening business as a food staller (Novikarumsar et al., 2020). According to Iskandar and Iskandar (2016), rice for local people has cultural value, so that it is only used during cultural events. Rice is also used for consumption, but not traded. Other sources that can be traded are petai (Parkia speciosa Hassk), durian (Durio zibethinus Murr), banana (Musa paradisiaca L.), taro, sweet potato, and gadung. Besides, Baduy people also work in other sectors besides agriculture such as being craftsmen, becoming guiders, and trading. Diversity of income sources makes Baduy community resilient to disasters (Iskandar and Iskandar, 2016). Indigenous people are very smart to survive by doing one or two types of work to make a living. This strategy makes the community very resilient to face Covid-19. This is mitigated by the strategy that they do not depend on the market but rather on fulfilling the necessities of life. Another strategy is that the Urug indigenous people do not want to do other work apart from agriculture.

For them, being a farmer is classified as a very noble job because of the viewpoint that peasants never deceive others and never envy each other. This perspective applies to the Covid-19 period. Agricultural work can still be done because it is a source of livelihood for everyone, including a source of food and vegetables. Preserving agricultural work means honouring humans because they can be made alive by these activities. Unemployment also does not occur in the Urug and Baduy indigenous people because they are still working on the land to produce rice as a reserve until the next planting season. The dismissal of agricultural workers also does not exist because everyone is the owner of the land. Everything depends on the farmer because he is the manager of his farming business. Meanwhile, agricultural workers such as labourer continue to work, so that there is no unemployment. In addition, farming is no longer a loss because the need for food is increasing during the Covid-19 period because people are at home, so they are wasteful of food. The tradition of preserving agricultural work has answered that farming can face Covid and make them strong because they can still work.

At the same time, Urug community does not lose their jobs, and their income is not reduced because agricultural production can still be done, especially rice. This condition is different from urban communities where they work as coolies, laborer, and employees and staff at large companies. When Covid-19 hits the urban social environment, it has an impact on unemployment. Consuello (2020) said that the factory which is mentioned as a big factory has halted to operate as well as a small company. For example, Ice Cream Aice, has laid off hundreds of workers. The main 
cause of the increase in unemployment during the pandemic was the existence of PSBB (largescale social restrictions), lockdowns, and social distancing. As unemployed cannot overcome, it results to jump social risk including poverty. Many urban dwellers have lost their jobs temporarily and permanently. As a result, office work that is considered noble has not been able to guarantee to build a resilient community for disasters and the Covid-19 outbreak. This is different from agricultural work where work can still run well without having to remove the job from the perpetrators.

\section{Conclusion}

Local wisdom can be interpreted as an idea, principles of life, behaviour, rules or norms, taboo and punishments as well as view of life that regulates life locally and globally valuable, so that it can regulate various ins and outs of life, including regulating and managing natural resources both in the living environment. In its application, local wisdom is very wise for the local community because all rules or norms and behaviour are based on a common agreement for a common goal, so that no individual is harmed. Besides, this knowledge has been tested in the field for a very long time from generation to generation, so that permanent knowledge is formed where this knowledge is classified as capable of overcoming all the shocks and disasters of life. Then, Urug society pays attention to a vulnerable group of the person such as orphans, elderlies, widows and persons who need most about aids from the person. Each person comprehends that they must allocate their prosperity like rice each year after harvesting to them because each person has chores to distribute the person entitlement. As eco-catastrophe combats the environment, the susceptible person is saved from a shortage of food. It can be strengthened by collective action like nujuh bulanan. In this action, household mother distributes traditional food to women who experience pregnancy. It can help women from the scarcity of food temporarily. Also, indigenous people use and implement and animate prohibitions as a way to regulate life, including dealing with Covid-19 and environmental disasters.

The prohibition behaviour is applied especially where people are not allowed to sell paddy and rice. This behaviour enables indigenous people to deal with Covid-19 because they do not lack food. Then, regulations in the form of prohibitions have an impact on the community's adaptation to Covid-19 and disasters because people can respond to the Covid-19 pandemic before the Covid-19 disaster hits the community. In addition, indigenous people combine livelihood strategies of more than one type at the same time, so that people can overcome the problem of disasters and Covid-19 because if a failure occurs, it can be overcome with other sources of life. Finally, indigenous people preserve agricultural work, so that unemployment does not exist during the Covid-19 pandemic and when disasters occur. This condition is different from the fact that in modern society, many people become unemployed and lose their jobs, so they become vulnerable in the face of Covid-19.

\section{References}

Adim, A. (2020). Pembentukan Tanggung Jawab Kerja Siswa Tunagrahita Pasca Sekolahsebagai Cleaning Service (Studi Etnografi di SLB Pembina tingkat Nasional bagian C malang). Jurnal Exponensial, 1 (1):37-50.

Ali, N., \& A. Sinilele. (2019). Kearifan Lokal Dalam Melestarikan Pulau Dan Laut Di Pulau Bonetambu Sulawesi Selatan. Hasanuddin Journal Of Sociology 1 (2):101-115.

Ayanlade, A., \& Radeny, M. (2020). Covid-19 and food security in Sub-Saharan Africa: implications of lockdown during agricultural planting seasons. npj Science of Food, 4(1), 1-6.

Beta, P, B. Herdiana \& Rinni Salvia. (2020). Etnografi Komunikasi Tata Cara Bertutur Masyarakat 
Suku Padoe. Jurnal Onoma: Pendidikan, Bahasa dan Sastra 6 (1):527-532.

Bhavani, R. V. \& R. Gopinath. (2020). The COVID19 pandemic crisis and the relevance of a farmsystem-for-nutrition approach. Food Security 12:881-884.

Consuello, Y. (2020). Analisis Efektifitas Kartu Pra-kerja di Tengah Pandemi Covid-19. Adalah: Buletin Hukum dan Keadilan, 4 (1):93-100.

Devereux, S., Béné, C., \& Hoddinott, J. (2020). Conceptualising Covid-19's impacts on household food security. Food Security, 12(4), 769-772.

Farkas, K. J., \& J.R. Romaniuk. (2020). Social Work, Ethics And Vulnerable Groups In The Time Of Coronavirus And Covid-19. Society Register 4 (2):67-82.

Galanakis, C.M. (2020). The Food Systems in the Era of the Coronavirus (Covid-19) Pandemic Crisis. Food 9 (523):1-10.

Gantini, T. (2015). Kearifan Lokal Dalam Metode Pengukuran Ketahanan Pangan (Local Wisdom Of Measurement Food Security Method). Majalah Ilmiah UNIKOM 13(2):212-220.

Gorda, A.N.S \& K.D.K.A. Wardani. (2020). Refleksi Nilai Kearifan Lokal Masyarakat Hindu Bali dalam Pengelolaan Lingkungan. Ettisal, jurnal of communication 91-107.

Habiba, U., Abedin, M. A., \& Shaw, R. (2016). Food security, climate change adaptation, and disaster risk. In Sustainable development and disaster risk reduction (pp. 87-101). Springer, Tokyo.

Habiba, Nurjihan, M.F. Nurdin and R.A.T. Muhamad. (2017). Adaptasi Sosial Masyarakat Kawasan Banjir di Desa Bojongloa Kecamatan Rancaekek. Sosioglobal : Jurnal Pemikiran dan Penelitian Sosiologi 2(1):40-58.

Harahap, R.H. (2020). Kearifan Tradisional Batak Toba Dalam Memelihara Ekosistem Danau Toba. Prosiding Seminar Nasional Pendidikan Antropologi (SENASPA), 1:1 - 18.

Hassen, T.B., H.E. Bilali \& M.S. Allahyari. (2020). Impact of Covid-19 on Food Behavior and Consumption in Qatar. Sustainability 12 (6973):1-18.

Honorene, J. (2016). Understanding The Role Of Triangulation In Research. Speciel Issue On Educational Evaluation \& Research 4 (31):91-95.

Hossain, S.T. (2020). Impacts of Covid-19 on the Agri-food Sector: Food Security Policies of Asian Productivity Organization Members. The Journal of Agricultural Sciences - Sri Lanka 15 (2): 116-132.

PPID Kab Bogor. (2020). Peta Sebaran Covid-9 Kabupaten_Bogor. Available at: https://ppid. bogorkab.go.id/?d=10690\&page_title=Peta_Sebaran_Covid-9_Kabupaten_Bogor

Ikhtiono, G., Bahagia, B., Wibowo, R., \& Mangunjaya, F. M. (2020). Land Conservation and Pest Management of Agriculture Perspective Islamic Religion. SALAM: Jurnal Sosial dan Budaya Syar-i, 7(11).

Ilhami, A, R. Riandi, S. Sriyati. (2018). Analisis kelayakan kearifan lokal ikan larangan sebagai sumber belajar IPA. Jurnal Bioedukatika 6 (1): 40 - 47.

Iskandar, J., And Iskandar, B.S. (2016). Kearifan Ekologi Orang Baduy Dalam Konservasi Padi Dengan "Sistem Leuit". Jurnal Biodjati, 2 (1):38-51.

Iskandar, J., \& Iskandar, B. S. (2016). Resilience of Baduy traditional agro-forestry systems in responses to environmental and socio-economic changes. Journal of Indonesian Natural History, 4(1), 19-24.. 
Jámbor, A., Czine, P., \& Balogh, P. (2020). The Impact of the Coronavirus on Agriculture: First Evidence Based on Global Newspapers. Sustainability, 12(11), 4535.

Koeswinarno. (2015). Memahami Etnografi Ala Spradley. Jurnal SMaRT 01 (02):257-265.

Kolodinsky, J., Sitaker, M., Chase, L., Smith, D., \& Wang, W. (2020). Food systems disruptions: Turning a threat into an opportunity for local food systems, Journal of Agriculture, Food Systems, and Community Development, Vol. 9, No.3, pp. 5-8.

Latifunnisa, Y \& D.L. Setyowati. (2019). Strategi Penghidupan Rumah Tangga di Das Garang Hulu. Geo Image 8 (1):45-52.

Lerebulan, M, M. Girsang, J.D. Siwalette. (2018). Pengelolaan Sumberdaya Alam Berbasis Kearifan Lokal (Studi Kasus Sasi Di Desa Watmuri Kepulauan Tanimbar). AGRILAN : Jurnal Agribisnis Kepulauan 6 (3):284-298.

Mawaddahni, S. (2017). Filosofi Hidup sebagai Wujud Kearifan Lokal Masyarakat Adat Kasepuhan Sinar Resmi. Local Wisdom 9 (1): 90 -102.

Mazlan \& Omar. (2012). Small is Big: The Charms of Indigenous Knowledge for Sustainable Livelihood, Procedia-Social and Behavioral Sciences 36:602 - 610.

Meagan, E., Schipanski, Graham, K., Macdonald., Rosenzweig, S., Chappell, M.J., Bennett, E.M., Kerr, R.B., Blesh, J.,Crews, T., Water, L.D., Jonathan, G., Lundgren, \& Schnarr, C. (2016). Realizing Resilient Food Systems. Bio Science, 66 (7): 600-610.

Mohajan, H. (2018). Qualitative Research Methodology in Social Sciences and Related Subjects. Journal of Economi Development, Environment and People 7(1):23-48.

Mouloudj, A. C. Bouarar, H. Fechit. (2020). The Impact Of Covid-19 Pandemic On Food Security. Les Cahiers du Cread 36 (03):159-184.

Mujahidin, E., Bahagia, R. Wibowo, F.M. Mangunjaya. (2020). Rereoangan Serumpi For Rural Development in Situ Udik Village West Java. JHSS (Journal of Humanities and Social Studies) 04 (02): 96 - 101.

Nasution, A.I, \& Taupiqqurrahman. (2020). Peran Kearifan Lokal Masyarakat Membuka Lahan Dengan Cara Membakar Sebagai Upaya Mencegah Kebakaran Hutan Dan Lahan. Jurnal Esensi Hukum 2 (1): 1-15.

Niman, E.M. (2019). Kearifan Lokal Dan Upaya Pelestarian Lingkungan Alam. Jurnal Pendidikan dan Kebudayaan Missio 11 (1):1-178.

Nugraha, A, R.H. Sudrajat, B.PS. Putri. (2015). Fenomena Meme di Media Sosial :Studi Etnografi Virtual Postng Meme Pada Pengguna Media Sosial Instagram. Jurnal SosioteknologiI 14 (3):237-245

Nugraha, A.S. (2020). Kearifan Lokal dalam Menghadapi Pandemi Covid-19: Sebuah Kajian Literatur. Sosietas 10 (1):745-753

Oktaviani, D, E. Prianto \& R. Puspasari. (2015). Penguatan Kearifan Lokal Sebagai Landasan Pengelolaan Perikanan Perairan Umum Daratan Di Sumatera. Jurnal Kebijakan Perikanan Indonesia 8 (1):1-12.

Omer, S. A., \& Hassen, N. A. (2020). The Impacts Of Covid-19 Pandemic Diseases On Ethiopian Agriculture: Food Systems, Industries, also Mitigation and Adaptation Strategy . Jurnal Ilmiah Pertanian, 17(1), 60-84.

Poudel, P.B., M.R. Poudel, A. Gautam, S. Phuyal, C.K. Tiwari, N. Bashyal, S. Bashyal. (2020). Covid-19 and its Global Impact on Food and Agriculture. Journal Biology Today's World 9(5): 
221.

Putra, D.F. \& A. Suprianto. (2020). Analisis Strategi Penghidupan Petani Kopi Desa Medowo Menggunakan Pendekatan Sustainable Livelihood. JPIG (Jurnal Pendidikan dan Ilmu Geografi) 5 (2):32-143.

Richards, T.J. \& B.Rickard. (2020). COVID $\square 19$ impact on fruit and vegetable markets. Canadian Journa Agriculture Economic 68 (2):189-194.

Rohmah, B.A. (2019). Strategi Penghidupan Berkelanjutan (Sustainable Livelihood) Masyarakat Di Kawasan Lahan Kering Desa Karangpatihan Kecamatan Balong Kabupaten Ponorogo. Swara Bhumi-e jurnal pendidikan geography fakultas FIS UNESA 1(2):1-10.

Manrique, D. R., Völker, T., Zoghbi, J., \& Pereira, Â. G. (2018). Arctic: Traditional Knowledge, Livelihoods and Community Engagement.

Rosmaidar. (2020). Kearifan Lokal Upacara Perkawinan Adat Suku Linggau. Jurnal Ilmiah Bina Bahasa 13 (1):37-46.

Seleiman, M.F., S.Selim, B.A. Alhammad, B. M. Alharbi, F.C.Juliatti. (2020). Will Novel Coronavirus (Covid-19) Pandemic Impact Agriculture, Food Security And Animal Sectors?. Bioscience Journal 36 (4):1315-1326.

Seprianto, D, P. Suminar \& H. Nopianti. (2017). Bukit Larangan: Prinsip Konservasi Masyarakat Berbasis Kearifan Lokal (Studi Kasus Desa Aur Gading Kecamatan Kerkap, Kabupaten Bengkulu Utara). Jurnal Sosiologi Nusantara 3 (2):37-45.

Siagian, T.H. (2020). Mencari Kelompok Berisiko Tinggi Terinfeksi Virus Corona Dengan Discourse Network Analysis. Jurnal Kebijakan Kesehatan Indonesia : JKKI 9 (2):98-106.

Singh, S., Kumar, R., Panchal, R., \& Tiwari, M. K. (2020). Impact of Covid-19 on logistics systems and disruptions in food supply chain. International Journal of Production Research, 1-16.

Skog, K.L., Eriksen, S.E., Brekken, C.A., \& Francis, C. (2018). Building Resilience in SocialEcological Food Systems in Vermont. Journal Sustainability, 10 (4813):1-16.

Sukadari, S, S. Suyata, S.A. Kuntoro. (2015). Penelitian Etnografi Tentang Budaya Sekolah Dalam Pendidikan Karakter Disekolah Dasar. Jurnal Pembangunan Pendidikan: Pondasi dan Aplikasi 3(2):58-68.

Sutigno, A.L \& B. Pigawati. (2015). Entuk Adaptasi Masyarakat Terhadap Bencana Rob Di Desa Sriwulan Kecamatan Sayung Kabupaten Demak. Jurnal Teknik PWK, 4 (4):499-513.

Syarif, E. (2017). Environmental Management in Local Wisdom Perspective of Karampuang People, Sinjai District, South Sulawesi. Sainsmat: Jurnal Ilmiah Ilmu Pengetahuan Alam, 6(2), 154-161.

Takiddin. (2014). Nilai-Nilai Kearifan Budaya Lokal Orang Rimba (Studi Pada Suku Minoritas Rimba Di Kecamatan Air Hitam Provinsi Jambi). Sosio Didaktika 1 (2):161-169.

Thohir, M. (2019). Etnografi Ideasional (Suatu Metodologi Penelitian Kebudayaan). Nusa: Jurnal Ilmu Bahasa dan Sastra 14 (2):194-205.

Tryanto. (2017). Kearifan Lokal Sebagai Langkah Awal Konservasi Sumberdaya Perikanan (Sebuah Pembelajaran dari Lubuk Larangan Sumatera Barat dan Reservat Perikanan Kalimantan Timur). Prosiding Pertemuan Ilmiah Masyarakat Limnologi Indonesia.

Udmale, P., Pal, I., Szabo, S., Pramanik, M., \& Large, A. (2020). Global food security in the context of Covid-19: A scenario-based exploratory analysis. Progress in Disaster Science, 7, 100120. 
Wahongan, A.S. \& M. Soputan. (2016). Keamanan Pangan Dengan Pendekatan Budaya Dan Kearifan Lokal Dalam Upaya Perlindungan Hukum Bagi Konsumen Di Minahasa Tenggara. Lex et Societatis IV (1):61-68.

Widarmanto, N. (2018). Kearifan Lokal Dalam Pengelolaan Sumberdaya Perikanan. Sabda 13 (1):18-26.

Workie, E., Mackolil, J., Nyika, J., \& Ramadas, S. (2020). Deciphering the impact of Covid-19 pandemic on food security, agriculture, and livelihoods: A review of the evidence from developing countries. Current Research in Environmental Sustainability, 100014.

Yang, L., Liu, M., Lun, F., Min, Q., Zhang, C., \& Li, H. (2018). Livelihood assets and strategies among rural households: Comparative analysis of rice and dryland terrace systems in China. Sustainability, 10(7), 2525.

Yanti, B., Priyanto, H., \& Zulfikar, T. (2020). Sosialisasi Waspada Infeksi Corona Virus pada Lansia di Panti Jompo Rumoh Seujahtra Geunaseh Sayang, Dinas Sosial Aceh. Martabe: Jurnal Pengabdian Kepada Masyarakat, 3(1), 67-72.

Zhou, H, X. Wang \& J. Wang. (2016). A Way to Sustainability: Perspective of Resilience and Adaptation to Disaster. Sustainability 8 (737):1-14. 